\title{
Semiotics on The Drama Script of "Mak, Ana Asu Mlebu Ngomah!" by Andy Sri Wahyudi
}

\author{
Y E Nugroho ${ }^{1}$, U Fuadhiyah ${ }^{2}$, D L Santi ${ }^{3}$

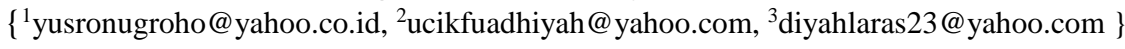 \\ ${ }^{1,2,3}$ Universitas Negeri Semarang, Indonesia
}

\begin{abstract}
The research problems in this research are (1) How is the index in the drama script Mak, Ana Asu Mlebu nGomah! by Andy Sri Wahyudi and its meaning? (2) How is the symbol in the drama script Mak, Ana Asu Mlebu nGomah! by Andy Sri Wahyudi and its meaning? (3) How does the drama script Mak Ana Asu Mlebu $n$ Gomah mean by Andy SW as a whole? The approach used in this research was an objective approach. This study contained descriptive data obtained by using heuristic and hermeneutic reading techniques to obtain the indexes and symbols contained in this drama script. Based on the results of the research, it can be concluded that indices and symbols were found in this drama script. The number of symbols found were 12 , while the index was 5 . These findings prove that this drama script is one of the prismatic literature. These signs indicated that there was an eviction of houses in a village. If it is examined more deeply in the meaning of the drama script, it shows the defense of the villager's identity from depraved things.
\end{abstract}

Keywords: Semiotics, Drama Script of Mak, Ana Asu Mlebu nGomah! by Andy Sri Wahyudi

\section{INTRODUCTION}

Literature are widely used by actors of arts and culture. A literature is used to express one's opinion and vision or his desired and believed life. A literature work does not only reveal an objective reality but also the views, interpretations, attitudes, and values of life based on creativity which its rightness can be accountable [1]-[3].

Drama is one type of literature. Nevertheless, drama is often only reviewed from the dimensions of the show. Even though the drama has two dimensions, namely the literary dimension, that is when the drama is still in the form of drama scripts, and the dimensions of the show, that is when the drama has been displayed. This research will examine drama from the literary dimension in the form of drama script [4].

At present, drama scripts, particularly Javanese drama scripts, are scarce. This scarcity is caused by the lack of interest from the reader to study or even read the play. Fuadhiyah [5] stated that the young generation has been hegemony by the development of various modern arts which were so repeatedly born and developed along with the development of technology and knowledge. The existence of films, soap operas, and various streams of modern music can provide distance between the younger generation with Javanese art. This phenomenon has become one of the factors causing young people to be less interested in Javanese drama. Besides, the lack of understanding the contents and elements of the drama is also a factor why the drama is less in demand. Therefore, to solve this problem the thing that can be done is by analyzing and knowing the meaning of what will be conveyed from Javanese drama scripts, namely by semiotic analysis.

The researcher chose the object of a drama with the title Mak, Ana Asu Mlebu nGomah! by Andy Sri Wahyudi [6] in Mak, Ana Asu Mlebu nGomah! 3 Javanese language play scripts published by Garudha Waca. This book was awarded as the best literary work from Balai Bahasa Yogyakarta (Yogyakarta Home of Language) in 2017. This script has just been staged on the Salatiga Theater stage. It is also the most widely played script in the Javanese Language Drama Festival in 2018 conducted by the Javanese Language and Literature Department, Universitas 
Negeri Semarang. As it is frequently played, it shows that this manuscript has more appeal than other Javanese drama scripts.

This script raises a few characters and highlights the character Asu in it. Asu is the spotlight and key points in the story. If you pay attention to Asu's character here, you don't do things as naturally as $A s u$ in real life. Asu's characters in this text can speak like a human being.

The drama script Mak, Ana Asu Mlebu nGomah! by Andy Sri Wahyudi is a literature that is not easily understood or known by prismatic literature. The relationship between signified and signifier or objects and representamen is not immediately understood to have to go through a process of understanding or interpretation. In addition, there has never been any research on the drama script Mak, Ana Asu Mlebu nGomah! by Andy SW both about the building elements and their signs and meanings. This research will focus more on the signs and meaning of signs from the elements of literary works, namely characters, settings, and plot contained in the Mak, Ana Asu Mlebu nGomah! by Andy Sri Wahyudi. As stated by Aston \& Savona [7] that the drama semiotic text bases its analysis on three elements, namely plot, character, and dialogue.

Hence, the purpose of this research is to be able to describe the index contained in the drama script Mak, Ana Asu Mlebu nGomah! by Andy Sri Wahyudi and its meaning, then it also describe the symbol found in the drama script Mak, Ana Asu Mlebu nGomah! by Andy Sri Wahyudi and its meaning, so that the latter can describe the overall meaning of the drama script Mak, Ana Asu Mlebu nGomah! by Andy Sri Wahyudi.

The theory used in this study is the theory presented by Charles Sanders Pierce. Pierce's theory says that a sign is something that refers to something else. Referring here means 'representing' or replacing instead of reminding. A sign is called a representamen while something else here is an experience, thoughts, feelings, ideas, etc. then this something is called an object [7]. Seeing that which can be a sign is actually not just language, but various things in life. In Pierce's theory there is a triadic triangle i.e., object, representamen, and interpretants. The three triadic relationships are then compiled into three trichotomies, namely trichotomy I, trichotomy II, and trichotomy III. In this study, the trichotomy II, the relationship between the sign and its reference consisting of icons, index, and symbols [8]-[12].

An icon is the relationship between the sign and its reference which has a similarity. It is classified into three more types, namely (1) Topological icons, the icon which the sign and its reference has spatial similarities. Therefore, this topological icon is often referred to as a spatial icon. For instance, maps, images, sketches, and others. (2) Diagramatic icon, the icon which the sign and its reference has relational or social resemblance. Fish signals someone's degree or it shows someone's caste. For example, the way someone sits when he meets with his king and other examples. (3) Metamorphosis icon or metaphor icon, this icon does not show the similarity between the sign and its reference, but the similarities between the two references to the referenced. For example, Diyah are like a rose. This sentence means that Diyah is a beautiful girl. Roses indicates a beautiful flower. Diyah and roses share similar characteristic, i.e. beautiful.

Index is a sign which has existential relationship. and has a cause and effect relationship with its reference. In addition, the reference is a proof of the sign so that the meaning of the sign can be interpreted as predicted. For example, overcast is a sign that it will rain, sunrise is a sign of morning, etc. [13].

A symbol is a sign which has already had a relationship with its reference conventionally. It means that there is an existing agreement between the use of the sign related to sign and its reference. The symbol is also arbitrary and should be explained to show a clear link between the sign and its reference. For instance, the green light on traffic signs. Drivers have already understood the convention that has been applied in the community that the green light means go. Thus, when there is a traffic light and it is green, they go. If it is red, they have to stop, and etc.

\section{RESEARCH METHOD}

The approach used in this research was an objective approach. This approach is more effectively used to analyze a literary text since Semi [14], argues that the objective approach focuses on the text itself and apart from other things that are outside it (extrinsic element). In this case, an objective approach is used to analyze the appearance of signs in the Mak Mak, Ana Asu Mlebu nGomah! drama script by Andy Sri Wahyudi so that the objective approach in this study is 
combined with Pierce's semiotic theory. This approach was used to obtain data in the form of signs (indices and symbols). The data source selected in this study, was the drama script Mak, Ana Asu Mlebu nGomah! by Andy Sri Wahyudi.

The data were obtained by heuristic and hermeneutic readings. Heuristic technique is the reading technique of first level literary works by reading as a whole while the hermeneutic technique is reading literary works in depth [15]. After reading the heuristics and hermeneutics, the data obtained was recorded into a data card. The data can be found by looking for signs that cannot be interpreted directly. It can be done by looking for signs which are the evidence of the object (index) or by looking for signs that arbitrarily or conventionally refer to the reference (symbols).

The data was collected and analyzed by the theory presented Charles Sanders Pierce about trichotomy of signs based on the relationship between the sign and its reference. Actually, the trichotomy is divided into three, namely icons, index, and symbols. Since the icon is a sign that has similarities to its reference, then the icon is a sign that has similarities to its reference. Thus, this research focuses more on indexes and symbols. After the data were grouped then they were interpreted using interpretation techniques. Ricoeur [16] says that interpretation is understanding the intent of a particular event. This technique was used to analyze the meaning contained in the data that have been collected.

\section{RESULTS AND DISCUSSION}

This chapter covers the signs (indices and symbols) contained in the drama script Mak, Ana Asu Mlebu nGomah! by Andy Sri Wahyudi and the meaning of these signs. The analysis was done by classifying the signs based on the relationship of the signs with their references, namely the index, the symbols contained in the characters, setting, and plot. After being interpreted one by one, the overall meaning starting from the beginning to the end of the story were interpreted afterward.

\subsection{Indices and meanings in the drama script Mak, Ana Asu Mlebu nGomah! by Andy Sri Wahyudi}

The drama script Mak, Ana Asu Mlebu nGomah! had some indices, namely flashlights, kreweng, the condition of Surip's house that was in disarray, the occurrence of Asu females appeared in their wings, and Asu brought home residents.

These signs have a causal relationship with their meaning or with the object. A flashlight indicates that it was night in the scene. Then, the next index that appears is kreweng. Kreweng is a sign that in the area where the incident occurred, there were many houses that were damaged.

The sign included in the next index is the messy condition of Surip's house. This sign indicates that $A s u$ tried to enter or damage the residents' houses starting from the Surip house. The next index is the occurrence of Asu female wings appear. This index is a sign that Surip must forget his ex-lover who has become Asu. The last index that appears is the Asu index to go home. This index is a sign that Asu damage or displace home residents.

\subsection{Symbols and meanings in the drama script Mak, Ana Asu Mlebu nGomah! by Andy Sri Wahyudi}

The drama script Mak, Ana Asu Mlebu nGomah! by Andy Sri Wahyudi is one of the prismatic literature as the meaning of the literature is indirectly known. Therefore, there are many symbols in this play. The symbols include Sumi, Surip, Mak Jiuk, Bakir, Cothot, Asu, gravestone, cakruk, quiet situation, sunrise, kissing, and gendera lan glogor.

The first symbol that appears is the Sumi figure. The Sumi character signifies children who lost their childhood happiness due to the arrival of Asu. The next symbol is the Surip character. Surip figure indicates that people who are not Asu are people who have a high spirit of struggle.

The next symbol is Mak Jiuk. Mak Jiuk shows that people who do not become Asu are people who like to work hard. The next symbol is Bakir. Bakir figure suggests that people who are 
not Asu are people who have concern for others. The next symbol is the Cothot figure. The Cothot figure indicates that people who are not Asu are persistent people who don't feel smart.

The next symbol is $A s u$. In general, Asu in this drama script indicates people who displaced people's homes. Still, if it is understood again, Asu is also a sign of things that are not good that try to enter into someone. In this drama script it rerfers to citizens. The next symbol that appears is gravestone. Kijing is the tomb of Mbah Karta which is an ancestor and the first person to live in the village. Kijing signifies the values of life that are held firmly by citizens or can be called identity.

The next symbol is cakruk. Cakruk indicates that the location of the event is on the edge of the city. The next symbol that appears is the quiet situation. This quiet atmosphere occurs at night. This symbol indicates that it will be someone who died. The following symbol in the drama script is sunrise. The sunrise signaling the event occurred in the morning.

The next symbol is kiss. Kissing signifies affection for someone who is kissed. In this text, the praises of love that have become Asu to Surip. The last symbol is gendera lan glogor. The gendera lan glogor is crossed by Bakir. This symbol indicates that someone died.

\subsection{The overall meaning of the drama script Mak, Ana Asu Mlebu nGomah! by Andy Sri Wahyudi}

Based on the semiotic analysis involving all three form relationships and the reference, that are an icon, an index, and a symbol, it is known that the meaning of drama Mak Ana Asu Mlebu $n$ Gomah! is about maintaining your identity. Asu as a dominant figure is a sign of things that are not good that try to influence citizens to come to be like him. Hence, the people's struggle to expel him symbolically is an effort to maintain their identity.

The analysis involving the icons, indexes, and symbols above makes the researcher considered that this drama script did not only tell about the eviction of a resident's house for the benefit of a particular person or group but was also a sign of efforts to maintain identity from the influence of things that were not good. Therefore, the title and contents indicate compatibility. Exclamation mark at the end of the title of Mak, Ana Asu Mlebu nGomah! shows rejection of the arrival of Asu which indicates bad things into the house that signifies their souls.

Based on this research, we can find out the true meaning of the Mak drama script, Ana Asu Mlebu nGomah! by Andy Sri Wahyudi. As stated by (Zaimar, 2014: 3) that the study of semiotics is a study that examines signs. (Kartika, 2014: 79) in his article also says that the study of semiotics is carried out to find out the true meaning in a literary work. Thus, this research is appropriate as it used semiotic analysis to find out the meaning in the drama script Mak, Ana Asu Mlebu nGomah! by Andy Sri Wahyudi.

\section{CONCLUSION}

Based on this research, 5 indexes and 12 symbols were found in this drama script. The more findings of the symbols over the index in this script proves that this drama script is one of the prismatic literature. The indices and symbols are found from characterizations, settings, properties used by the characters, and dialogue and behavior instructions. Aston \& Savona (in Sahid 2016:30) stated that semiotics in drama script bases its analysis on three elements, namely plot, character, and dialogue.

After being interpreted one by one, the indices and symbols show that the drama script Mak, Ana Asu Mlebu nGomah! by Andy Sri Wahyudi tells the story of residents who are trying to defend their homes that will be evicted, and maintain identity from bad influences.

\section{REFERENCES}

[1] T. Suwondo, Studi Sastra: Konsep Dasar Teori dan Penerapannya pada Karya Sastra. Yogyakarta: Gama Media, 2011.

[2] T. Suwondo and R. Sukesti, Eds., MOZAIK Upaya Pemasyarakatan Bahasa dan Sastra. 
Yogyakarta: Departemen Pendidikan Nasional Pusat Bahasa, Balai Nahasa Yogyakarta, 2003.

[3] S. K.M., Protes Sosial Dalam Sastra. Bandung: Angkasa, 1986.

[4] J. Van Luxemburg, M. Bal, and W. G. Westseijn, Pengantar Ilmu Sastra. Jakarta: Gramedia, 1989.

[5] U. Fuadhiyah, "Analisis Struktural Naskah Drama Berbahasa Jawa Sadumuk Bathuk Sanyari Bumi Karya Arih Numboro," Jurnal Lingua, vol. 9, no. 2, pp. 18-25, 2013.

[6] A. S. Wahyudi, Mak, Ana Asu Mlebu nGomah! 3 Naskah Lakon Bahasa Jawa. Yogyakarta: Garudhawaca, 2014.

[7] N. Sahid, Semiotika Untuk Teater, Tari, Wayang Purwa dan Film. Semarang: Gigih Pustaka Mandiri, 2016.

[8] O. K. S. Zaimar, Semiotika dalam Analisis Karya Sastra. Depok: PT Komodo Books, 2014.

[9] E. W. B. Hess-Lüttich, "Semiotics: The Basics," Journal of Pragmatics, vol. 35, no. 6, pp. 927-930, 2003.

[10] G. Deledalle, Charles S. Peirce's philosophy of signs : essays in comparative semiotics, vol. 55. 2000.

[11] J. Culler, The Pursuit of Signs: Semiotics, Literature, Deconstruction. London - New York: Routledge, 2001.

[12] R. Stam, R. Burgoyne, and S. Flitterman-Lewis, NEW VOCABULARIES IN FILM SEMIOTICS Structuralism, post-structuralism and beyond. London - New York: Routledge, 1992.

[13] Y. Kartika, "Analisis Semiotika Teks Drama Kau Tunggu Siapa Nilo Karya Wisran Hadi," Jurnal Pendidikan Bahasa dan Sastra Indonesia, vol. 1, no. 1, pp. 79-86, 2014.

[14] M. A. Semi, Metode Penelitian Sastra. Bandung: Angkasa Raya, 1993.

[15] T. Supriyanto, Kajian Stilistika dalam Prosa. Yogyakarta: Elmatera Publishing, 2014.

[16] P. Ricoeur, Teori Interpretasi. Yogyakarta: IRCiSoD, 2014.

[17] K. Saddhono and S. Supeni. "The role of dutch colonialism in the political life of Mataram dynasty: A case study of the manuscript of Babad Tanah Jawi." Asian Soc. Sci. vol. 10 no.15 pp. 1-7, 2014 